\title{
Wastewater Management in Third World Cities: Case Study of Cotonou, Benin
}

\author{
Sena Peace Hounkpe ${ }^{1}$, Edmond Codjo Adjovi'2, Martin Crapper' ${ }^{1}$, Esi Awuah ${ }^{3}$ \\ ${ }^{1}$ School of Engineering, The University of Edinburgh, Edinburgh, UK \\ ${ }^{2}$ Civil Engineering Department, Université d'Abomey-Calavi, Cotonou, Benin \\ ${ }^{3}$ Department of Civil Engineering, Kwame Nkrumah University of Science and Technology, Kumasi, Ghana \\ Email: senapeace@yahoo.fr
}

Received 27 December 2013; revised 25 January 2014; accepted 23 February 2014

Copyright (C) 2014 by authors and Scientific Research Publishing Inc.

This work is licensed under the Creative Commons Attribution International License (CC BY). http://creativecommons.org/licenses/by/4.0/

\section{Abstract}

Poor wastewater management coupled with lack of sanitation facilities has aggravated the sanitation challenges in developing countries. This study was aimed at providing information on the current state of sanitation in Cotonou City through surveys. The most common sanitation facilities in the city were septic tanks, latrines and soakaway pits. Mechanical desulging was mainly used (94\%) for desludging latrines and septic tanks with a frequency of less than once a year for $73 \%$ of the houses; manual desludging was most common for soakaway pits. $84 \%$ of sullage generated is disposed without treatment. The only existing stabilization pond plant, managed by a private company SIBEAU, is overloaded; the effluent is poor (up to $2250 \mathrm{mg} / \mathrm{lBOD}_{5}$ ) and does not meet any quality standards. $96 \%$ of survey respondents recognise that the sanitation situation in the city is not good; it has to be improved by providing an appropriate and sustainable sanitation management system.

\section{Keywords}

Urban Sanitation, Septic tanks, Soakaway Pits, Latrines, Desludging, Wastewater Treatment, Developing World Cities

\section{Introduction}

The inappropriate disposal of municipal wastewater poses a great threat to the environment and public health because human excreta is responsible of the transmission of several infectious diseases which affect millions of people in the world. According to the WHO, the major part of all illness in developing countries is caused by water and sanitation related diseases [1] [2]. UN-water identified diarrhoea as second in the list contributing to the 
global burden of disease-ahead of heart disease and HIV/AIDS. It is estimated that 1.5 million deaths among children under five each year are due to diarrhoea, mostly in developing countries; this is equivalent to "a child dies every 21 seconds" [3]. Proper disposal of wastewater is thus necessary to protect the environment and public health, and also to prevent unsightly and unpleasant odours.

Sanitation is a major environmental issue in developing countries. Most of the 2.6 billion people in the world with unimproved sanitation facilities live in Southern Asia, Eastern Asia and Sub-Saharan Africa. Africa has the highest proportion of people using unimproved or shared facilities. Sanitation coverage in Sub-Saharan Africa is estimated at $31 \%$, with about $44 \%$ of the urban population using improved sanitation [4]. In developing-world cities, with rapid urban population growth, it is a great challenge to stakeholders to provide basic services [5]. The problem is more accentuated in sanitation because, for quite a long period, authorities in developing countries have concentrated their efforts on providing the population with drinking water as a priority [6].

As a result, in Sub-Saharan Africa, if sanitary facilities are available, they usually consist of on-site individual systems (latrines and septic tanks) with a high quantity of excreta (faecal sludge) to manage [7]. In most main cities, if wastewater is not collected by individual systems, it is discharged untreated onto the street or into the public storm water drains, with subsequent contamination of water bodies and health risks [8].

The objective of this study is to provide detailed information, through surveys, on the present situation in Cotonou, the main city of Benin. The field surveys attempted to discover the different type of sanitation facilities available, the fate of "black water" (domestic wastewater containing faeces) and sullage (other domestic wastewater mainly from kitchen, laundry and bathrooms) generated at household level and at the city level, and to evaluate the appropriateness and performance of the existing treatment plant and the proportion of wastewater channelled to the plant. In addition, the surveys attempted to determine public perception of wastewater management in the city of Cotonou.

\section{Materials and Methods}

\subsection{Description of Study Area}

Cotonou is the economic capital city of the Republic of Benin, which is one of the smallest countries in West Africa. The country is bordered on the north by Niger, on the North West by Burkina-Faso, on the west by Togo, on the south by the Gulf of Guinea and on the east by Nigeria (Figure 1).

Cotonou is located in the Littoral Region, a coastal area of Benin. The estimated population as at 2006 was 761,137 [9]. It is the biggest city in Benin where most of the political, administrative, economic, industrial, cultural and tourist activities are concentrated. The city is part of the subequatorial zone, with temperatures ranging between 24 and $28^{\circ} \mathrm{C}$ and an annual average sunshine of 2290 hours. The relative humidity is between $60 \%$ and 90\%. Rainfall in Cotonou is bimodal (April to mid-July and mid-September to October) and there are two dry seasons (mid-July to mid-September; November to mid-March). During the rainy seasons, the annual average rainfall recorded at the station at Cotonou Airport between 1953 and 2007 was $1308 \mathrm{~mm}$; the minimum and the maximum rainfall recorded during this period are respectively $719.4 \mathrm{~mm}$ in 1977 and $2470.2 \mathrm{~mm}$ in 1968 [10].

The city is on a plain with a sandy soil. The thickness of the soil is less than $4 \mathrm{~m}$. The porosity varies between $35 \%$ and $40 \%$ and the infiltration capacity is from $7 \%$ to $20 \%$, depending on the level of the groundwater. The major characteristic of the soil is the presence of groundwater at a very shallow and fluctuating depth (0 to $6 \mathrm{~m})$. Because of this, although the soil is very permeable, Cotonou is quasi- flooded almost all year round [10].

\subsection{Households and Housing Structure}

Cotonou has thirteen suburbs and 144 areas. The number of households in Cotonou was estimated at 154346 in 2002, with an average household size of 4.31. The housing structure of Cotonou is very diverse, with a preponderance of simple buildings in compounds fenced by a wall with one or several courtyards. Most of the house occupants are tenants (49\%), some are owners (19\%), $27 \%$ are family houses and the remaining ones are staff quarters or others [11].

Most housing (79\%) consists of tenement-type buildings (compounds), shared by several households. In these, shared sanitation facilities are common (Figure 2). In general multi-storey buildings (4\%) and villas (4\%) have in house water supply and WCs as sanitation facilities. Villas are dwellings for a single household; multi-storey buildings mostly accommodate several households and the sanitation disposal facilities are shared and each 


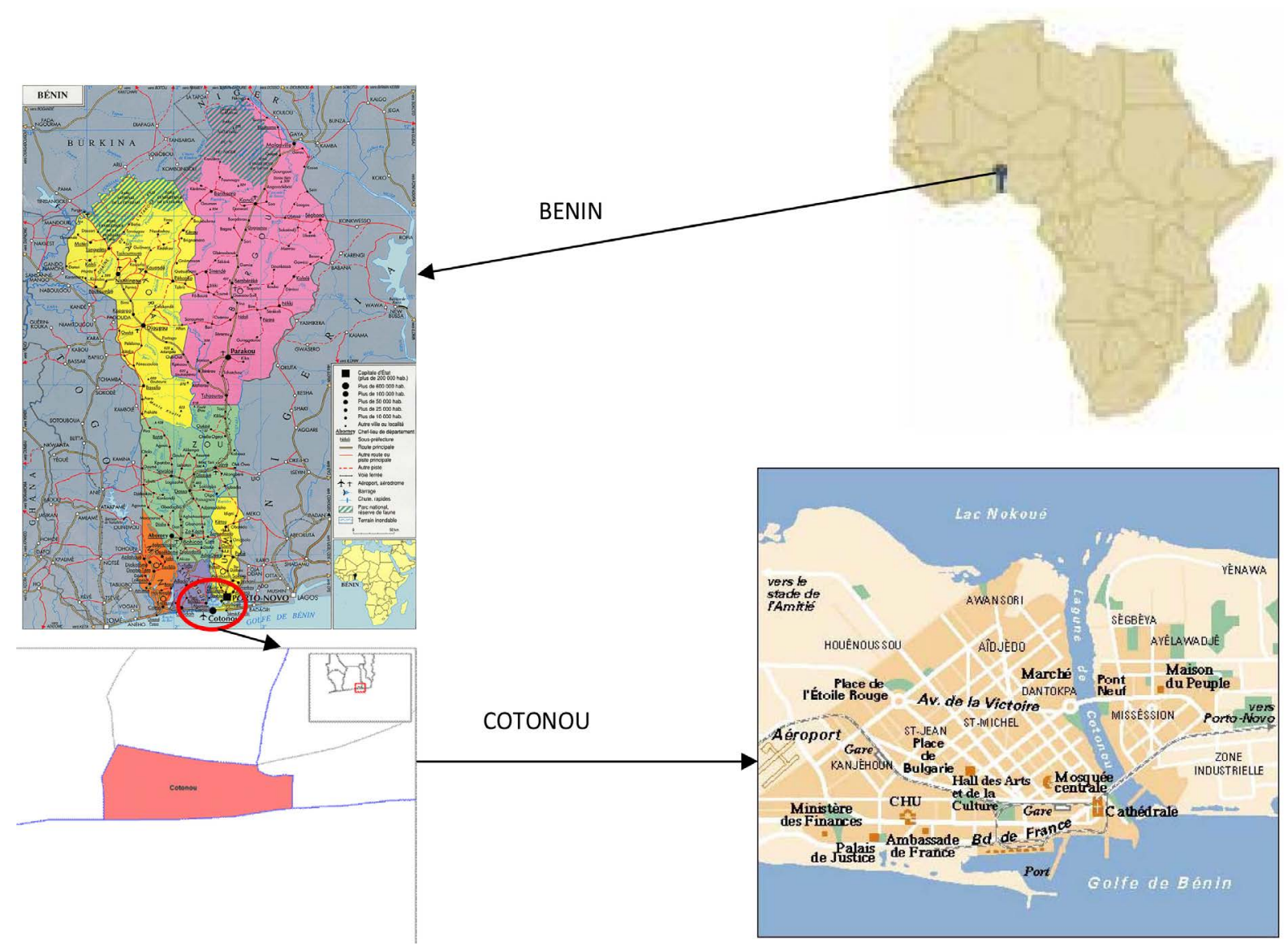

Figure 1. Study site’s map.
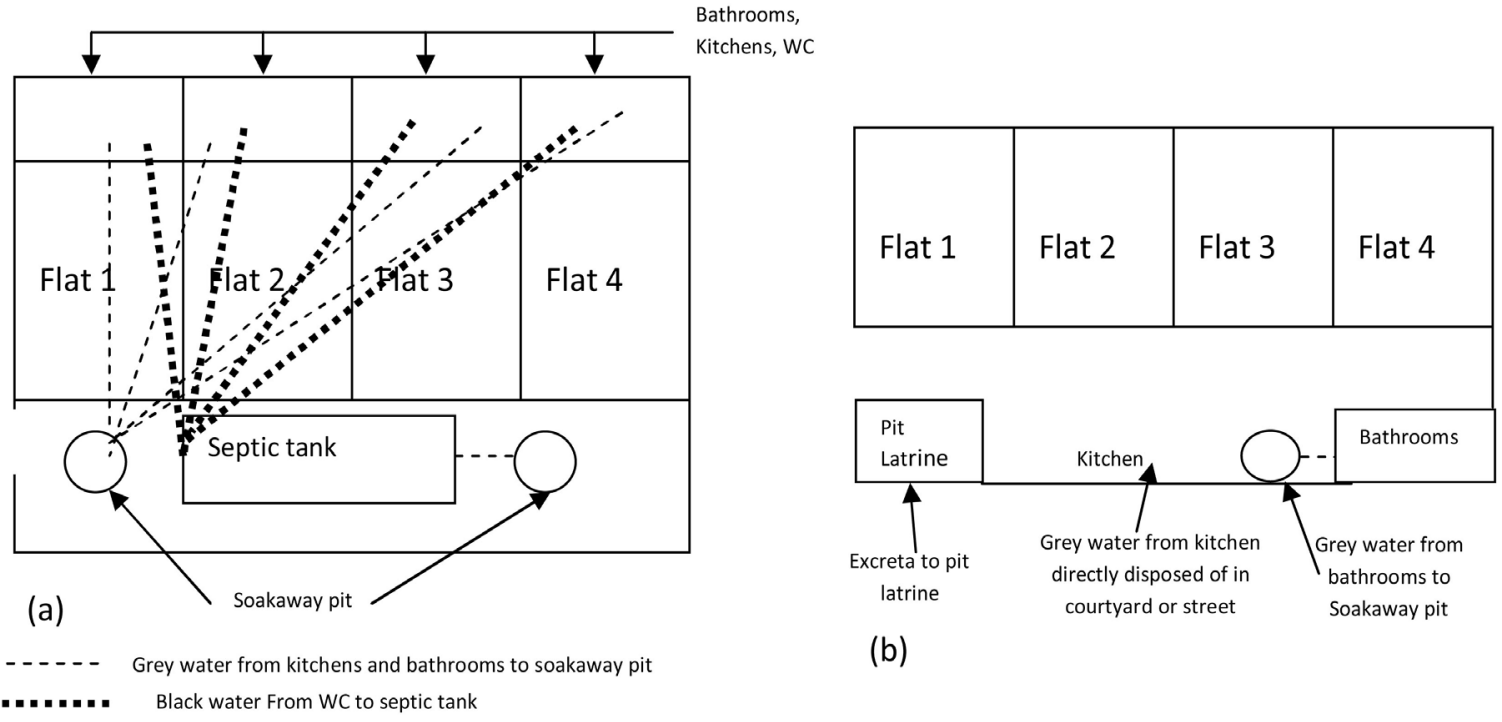

(b)

Figure 2. Typical structure of house. (a) With WC; (b) With pit latrine.

household has to contribute for desulging. The remaining types of houses are huts (constructed of precarious materials) and detached houses. The sanitation facilities in these depend on their location and the accessibility of a water supply. Most of the huts do not have any sanitation facilities on the property [11]. 


\subsection{Treatment Plant Description}

The only treatment plant for wastewater from Cotonou and surrounding areas (Sèmè-Kpodji and AbomeyCalavi) consists of two series of three waste stabilisation ponds receiving effluent from an anaerobic pond (Figure 3). The plant was installed from 1991 and was opened in 1994 under the management of a private company SIBEAU (Société Industrielle Béninoise de l'Environnement et de l'Aménagement Urbain). It is located at Ekpè (Sèmè-Kpodji), 13 km to the east of Cotonou and receives waste by road tanker services.

\subsection{Data Collection at House Level}

In this study, a questionnaire was the main tool used. The questionnaire had four sections-socio-demography, water resources and supply, wastewater disposal and economics. The questions were both open and closed format. They were administered by face-to-face interviews. The survey was conducted from February to March 2010. The languages for the interviews were either Fon or French, depending on the respondents' choice.

The number of households to be surveyed was calculated by:

$$
n=\frac{t^{2} p(1-p)}{m^{2}}
$$

$n$ : minimum sample size required to obtain meaningful results for an event and the level of risk attached; $t$ : Confidence Level ( typical value of the confidence level of $95 \%$ is 1.96 ), it is the probability that the chosen sample have influenced the results obtained;

$p$ : Probability of occurrence of the event, it is the percentage of people who have the observed character;

$m$ : Margin of error (usually set at $5 \%$ ), which expresses the extent to which our results reflect the reality at the household level ( our population);

As part of this work the probability of occurrence is taken equal to the rate of sanitation coverage in urban areas in Sub-Saharan Africa published by WHO is 44\% [4].

To take into account the parent population $(N)$, a correction factor is applied; it is given by:

$$
n^{\prime}=\frac{n}{1+\frac{n+1}{N}} \approx \frac{n}{1+\frac{n}{N}}
$$

And finally to account for contingencies such as non-responses or mistakes in recording a rate of $20 \%$ was added to the calculated value. Thus, a final minimum number of 455 households were obtained, value that was rounded to 460 .

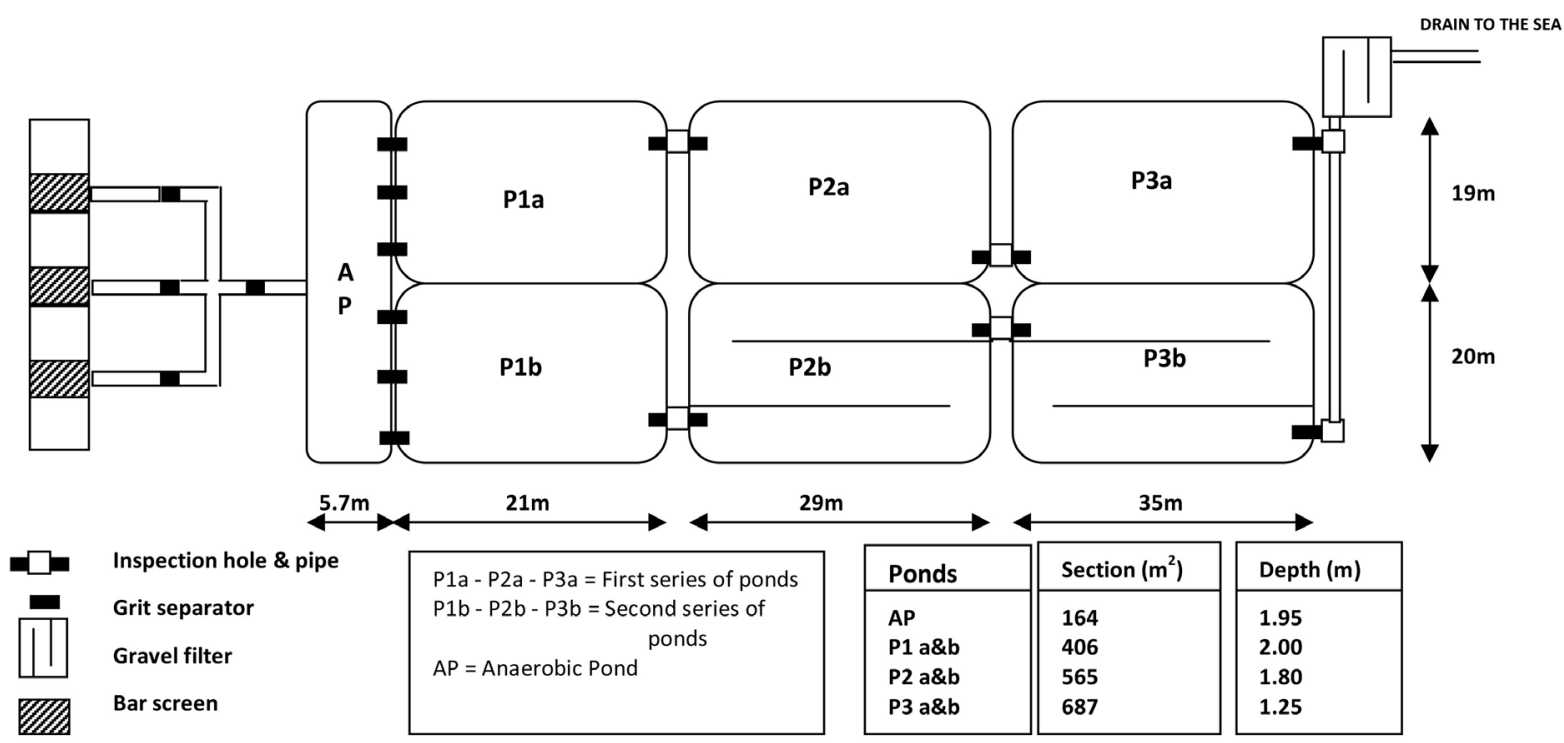

Figure 3. EKPE’s treatment plant. 
Simple random sampling was used to select houses in 26 areas using a city map in order to cover the whole city and different income areas. Questionnaires were administered in 460 houses. 448 responses were validated while 12 were discarded for various reasons such as non-response to some major questions. The 448 houses responding represented about 5400 persons with an average of 12.1 persons per house and 3.9 households per property.

\subsection{Treatment Plant Data Collection}

The study focused on data on the treatment plant for the period from January 2008 to April 2010, collected at the plant management headquarters. To validate the data, the researcher stayed on site for a week to monitor activities at the treatment plant. The plant opens for receipt of wastewater at 7 am and closes at 6 pm every day excluding Sundays and holidays. In order to be able to cover the working hours of the plant a BSc student was employed to assist with data collection. Data collected by the researcher was compared with that of the plant workers.

The information gathered were the number and capacity of trucks coming into the plant each day, the name of the truck operating company, the provenance of wastewater (septic tank, soakaway pits, and latrines) and the fees paid.

Another questionnaire was designed and administered to the managers of the treatment plant. The questions covered the relationship between the management board and municipality, management problems and proposed solutions.

To estimate the treatment performance of the plant, some parameters were measured. The $\mathrm{pH}$, temperature, conductivity, and dissolved oxygen were measured on site. The $\mathrm{pH}$ and temperature were measured with the pH-meter pH 3110 SET 3 (WTW) of \pm 0.01 of accuracy in accordance with the standard NF T 90-008.

The electrical conductivity, in $\mu \mathrm{S} / \mathrm{cm}$ (micro-Siemens per centimetre), was measured with a conductivitymeter pH/EC/TDS Waterproof Family in accordance with the standard NF EN 27888 class index T 90-031.

To obtain the Chemical Oxygen Demand (COD) and the Total Suspended Solid (TSS), the volumetric method and the filtering method were used respectively according to AFNOR standards (NFT 90-101 and NF EN 872). As for the determination the Biochemical Oxygen Demand at 5 days of incubation $\left(\mathrm{BOD}_{5}\right)$, membrane manometers (Oxitop) were used (Standard NF T 90-103).

\subsection{Data Analysis}

The responses were standardized and registered into a file. Data analysis was then done by calculating the frequency of the relevant variables (such as sources of water in house, desludging frequency) and means (average house or household size, plant influent and effluent quality) using Microsoft Excel tools.

\section{Results and Discussion}

\subsection{Social Characteristics}

The respondents were representatives of their houses. They were all above eighteen years old. $56 \%$ were the heads of a household in the house or their spouses. 34\% were the children of the heads of household above 18 years old and the rest were other members of the family. $54 \%$ of the respondents were female.

The households were classified into income levels (Table 1).

The sizes of houses based on the number of occupants showed that majority of the respondents (30.9\%) used the medium-sized houses (Table 2). The number of occupants may explain the frequency of desludging of faecal sludge (and the type of houses and the occupant status). Most of the small sized houses were villas or huts for one household, while the extra large houses had more than five households. The most common structures of houses with several households are as shown in Figure 2.

\subsection{Water Supply for Domestic Purposes}

$56 \%$ of the households surveyed had an in-house tap connected to the public water supply network; this percentage is higher than the estimated percentage of people having piped improved water connection in urban areas of Benin and smaller than the estimated percentage (84\%) of people using improved drinking water sources 
Table 1. Classification of sample as per income level.

\begin{tabular}{ccc}
\hline Income level & Income range & Percentage \\
\hline Very low & US\$0 to US\$ 110 & $20.7 \%$ \\
Low & US\$110 to US\$ 220 & $43.9 \%$ \\
Medium & US\$220 to US\$ 440 & $24.6 \%$ \\
High & More than US\$ 440 & $10.7 \%$ \\
\hline
\end{tabular}

Table 2. Classification of houses per number of occupants in a house.

\begin{tabular}{ccc}
\hline Size & Number of occupants & Percentage \\
\hline Small & 0 to 5 persons & $21.7 \%$ \\
Medium & 6 to 10 persons & $30.9 \%$ \\
Large & 11 to 15 persons & $19.7 \%$ \\
Extra large & 16 to 20 persons & $15.1 \%$ \\
Extra Extra large & More than 20 persons & $12.6 \%$ \\
\hline
\end{tabular}

in urban areas of Benin by WHO [4] [5]. The differences in the percentages can be explained by the fact that most of the households having access to public water supply did not have in-house piped distribution; they had only a stand pipe (most of the time at the entrance). In those cases, the water was used mainly for drinking and commercial sale. In houses without public water supply, residents relied on water sources such as wells or the lagoon for domestic purposes such as laundry, washing, bathing, cooking and other purposes like car washing and gardening, but in most cases they buy water for drinking and thus have access to improved drinking water without being connected directly to public water supply. Some people having in-house connection to the public water supply also had wells.

$81 \%$ had wells whilst $9 \%$ did not have any water supply (no well or stand pipe) in the house. The latter category either used neighbouring wells or lagoon water (for those near to the lagoon) for domestic purposes, and sometimes bought water for drinking from neighbours. Some people (5\%) used water from wells for drinking (Figure 4).

\subsection{Wastewater Management at Household Level}

- Sullage Management

In most houses (59.7\%), sullage from the bathroom is diverted to a soakaway pit attached to the septic tank, or to a completely separate soakaway pit. $1.8 \%$ had connected their bathrooms to public stormwater drains, whilst the others dispose of their sullage directly onto the street, into the lagoon, into their backyard or courtyard. Most of the wastewater from the other domestic uses was discharged directly into the environment (Figure 5).

Most of soakaway pits were constructed of concrete blocks with cement lining (Figure 6(a)); some, however, were just a whole dug into the soil.

Due to the shallow groundwater table, soakaway pits discharge directly into the groundwater, especially during the rainy season when the water level in the soakaway pits rises due to the infiltration of groundwater. This makes desulging of the soakaway pits necessary because waters from the pits should not be allowed to infiltrate into the ground. For the same reason, the pits' depth is often very small, leading to the need for frequent emptying. $60.7 \%$ of houses having soakaway pits desludged them. $54.9 \%$ of the houses (that means $90.4 \%$ of those who desludge their soakaway pits) desludged their soakaways at most once a year. On the other hand, 39.3\% of houses do not empty their soakaway pits; they leave them running onto the street, the backyard or the courtyard (Table 3, Figure 6(b)).

Only $25.5 \%$ of the respondents had their soakaway desludged by means of vacuum tankers, finally disposing of the effluent at the treatment plant. To reduce cost, $35.2 \%$ of houses used manual emptying; they then directly disposed of their sludge in the environment by burying it, throwing in public drain or onto the street (Table 4). This practice seems to be common in Sub-Saharan cities. It has been estimated that $45.3 \%$ of sludge removed manually from toilet facilities in Ouagadougou is disposed of onto the street, $23.2 \%$ at other places and the remaining used as compost [6].

By combining information from Figure 5 and Table 4, it can be determined that only 15\%, $8 \%$ and 2\% of the 


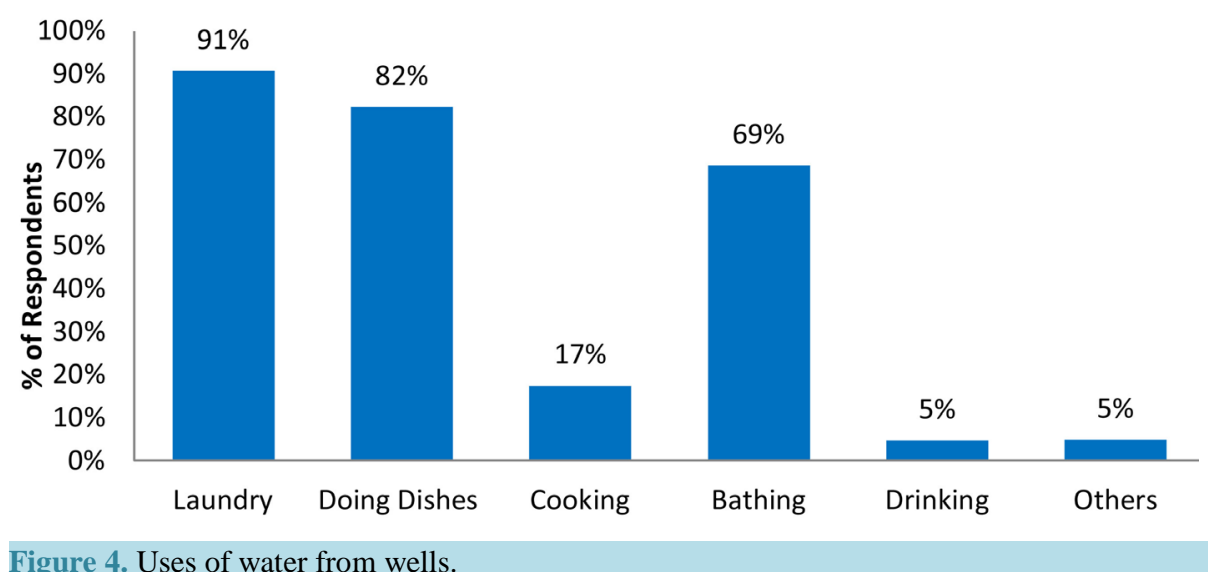

Figure 4. Uses of water from wells.

- From Bathroom From kitchen = Laundry and others

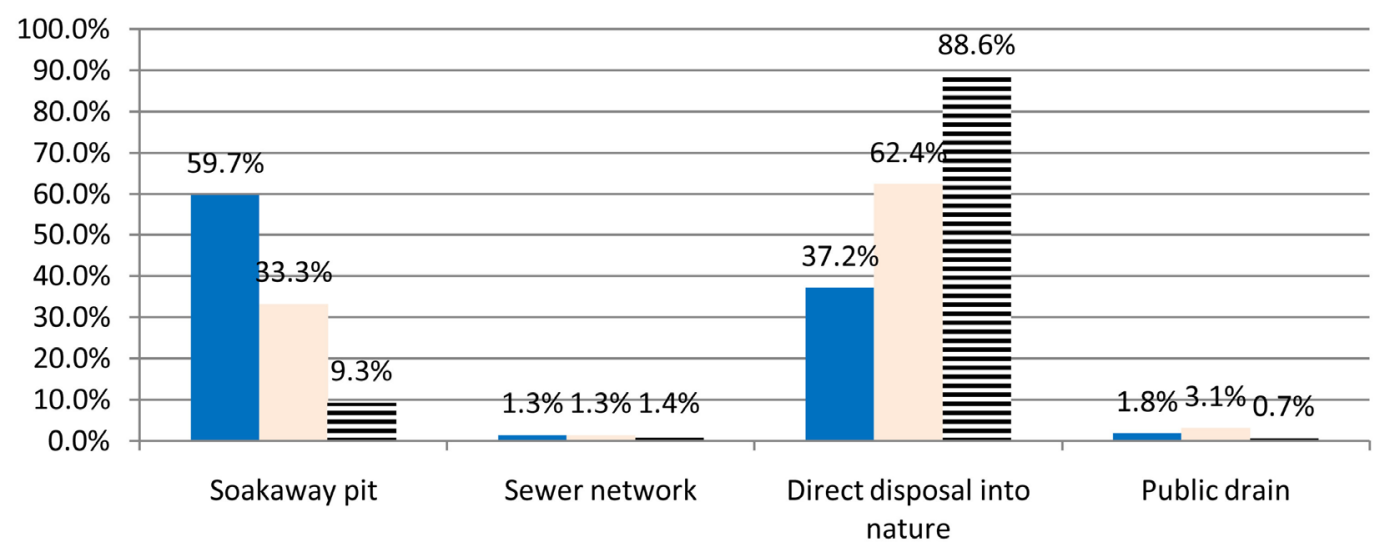

Figure 5. Sullage disposal.

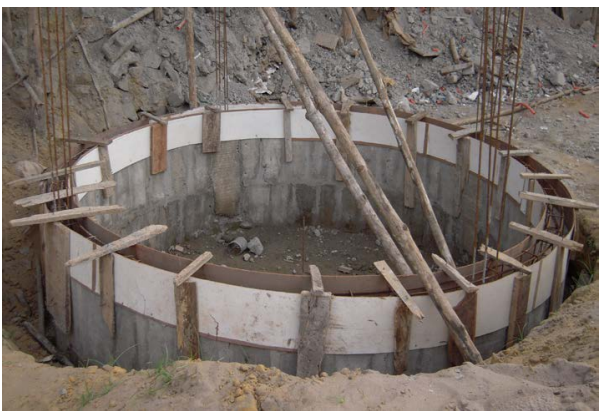

(a)

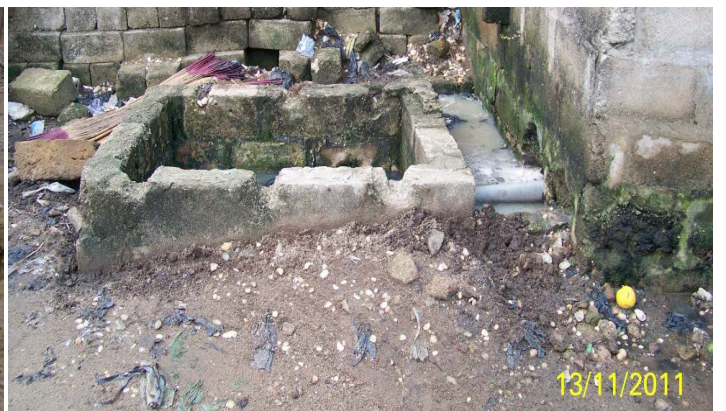

(b)

Figure 6. Soakaway pit. (a) under construction (b) current never emptied.

Table 3. Desluging frequencies of facilities.

\begin{tabular}{ccc}
\hline Desulging frequncy (in months) & Soakaway pits & Toilet facilities \\
\hline 0 to 6 & $22.7 \%$ & $22.0 \%$ \\
6 to 12 & $32.2 \%$ & $51.3 \%$ \\
12 to 24 & $3.7 \%$ & $13.9 \%$ \\
24 to 48 & $1.7 \%$ & $4.8 \%$ \\
More than 48 & $0.4 \%$ & $2.6 \%$ \\
Never desludged & $39.3 \%$ & $5.4 \%$ \\
\hline
\end{tabular}


Table 4. Desulging means of soakaway pits and toilet facilities (latrines or septic tanks).

\begin{tabular}{ccc}
\hline Desulging means & Soakaway pits & Toilet facilities \\
\hline Mechanical (vacuum tankers) & $25.5 \%$ & $94.3 \%$ \\
Manual & $35.2 \%$ & $0.3 \%$ \\
Never desludged & $39.3 \%$ & $5.4 \%$
\end{tabular}

sullage generated from the bathrooms, kitchen, laundry and other places respectively is diverted to the treatment plant. The remaining sullage is disposed of into the open environment (street, courtyard and backyard), surface watercourses or storm water drains. These findings indicate that house owners are not concerned about sullage disposal especially in low income houses where, most of the time, no facility exists for sullage collection. 84\% of houses using a well for domestic purposes were diverting their sullage directly into the environment suggesting that the potential for a link between sullage disposal and contamination of drinking water was not being made by the residents.

- Black Water Management

Types of Toilet Facilities

Most of the houses in Cotonou (82.7\%) were using individual sanitation facilities (traditional latrine, septic tank). The superstructure of latrines is usually made of brick with cement mortar (rarely in bamboo or sheet metal) and roofed with sheet metal or a solid concrete slab. The pits consist of a concrete slab or cement mortar base, with the sides in brick coated with cement mortar and covered by a concrete slab with a hole to receive the excreta. Almost all the pits had a depth of between 1.0 and $2.5 \mathrm{~m}$, due to the shallow groundwater table. In the case of depths greater than $1.0 \mathrm{~m}$, the remaining part of the pit was an above-ground superstructure (Figure 7).

Houses with septic tanks had WCs with sewer lines connected to the septic tank. Black water is thus diverted to the septic tank, with the effluent from the septic tanks being discharged into soakaway pits.

Only 2.2\% of the houses were connected to a sewer network. These were located in "Cité Vie Nouvelle" area, where there is an old sewer network discharging directly into the sea.

This percentage of houses connected to sewer is very close of that (2\%) noticed in Yaounde and Douala (Cameroun). Less than $0.5 \%$ of houses of Niamey (Niger), $5 \%$ of those of Kumasi (Ghana) and 30\% at Abidjan (Cote d'Ivoire) and Dakar (Senegal) were reported to be connected to a sewer. It has been reported that more than 93\% of the household of Ougadougou (Burkina Faso) were using individual on-site toilet facilities [6] [12] [13]. The observed data shows that in Sub-Saharan Africa Cities, the most common sanitation facilities are individual.

Of surveyed houses, $15.1 \%$ did not have any toilet facilities (Table 5); they used their neighbours' latrines, public latrines (9.0\%), or practised open defecation. Those close to the lagoon had built structures on the lagoon which are used for privacy when they defecate directly into the lagoon. These are called "lagoon latrines" (Figure 8.). This percentage (15.1\%) is far higher than that (5\%) observed through a survey in Ouagadougou [6] but lower than the estimated percentages for urban areas in Benin (31\% for open defecation and 34\% for shared facilities) and for Sub-Saharan Africa urban areas in general (25\%) by WHO [4] [5].

This difference from the WHO data can be explained by the fact that open defecation and shared facilities are more extensively used in other cities of Benin than in Cotonou due to the high urbanisation of the city and existence of few areas allowing privacy for open defecation.

The type of toilet facility depends on income level and accessibility to public water supply. All the houses with WCs with an automatic flushing system had an in-house water connection and distribution network. They represented $50 \%$ of those having an in-house connection to public water supply and comprised all (100\%) the high income households. $67 \%$ of the houses without in-house connections to the public water supply had a latrine or manual flushing WC. Most of the houses without in-house toilet facilities (83\%) were in low or very low income houses; they represented $24.5 \%$ of low or very low income houses (Table 6, Table 7).

Mode and Frequency of Desludging

Toilet facilities such as latrines and septic tanks require emptying when full. Most households (94.3\%) emptied their systems using mechanical vacuum tanks. Some (5.4\%) had never emptied their facilities because they were not yet filled or they do not have any facility (Table 4). This result showed that manual desludging of toilet facilities is less common in Cotonou than in other cities of Sub-Saharan Africa like Ouagadougou where the per- 


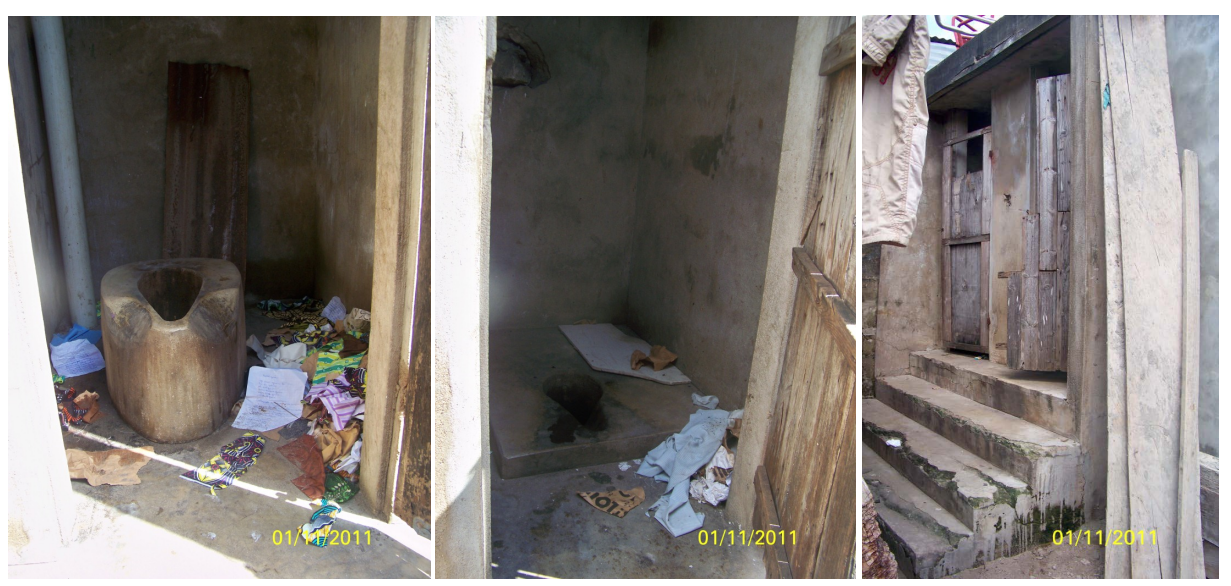

Figure 7. Typical traditional latrine in Cotonou and anal cleansing materials.

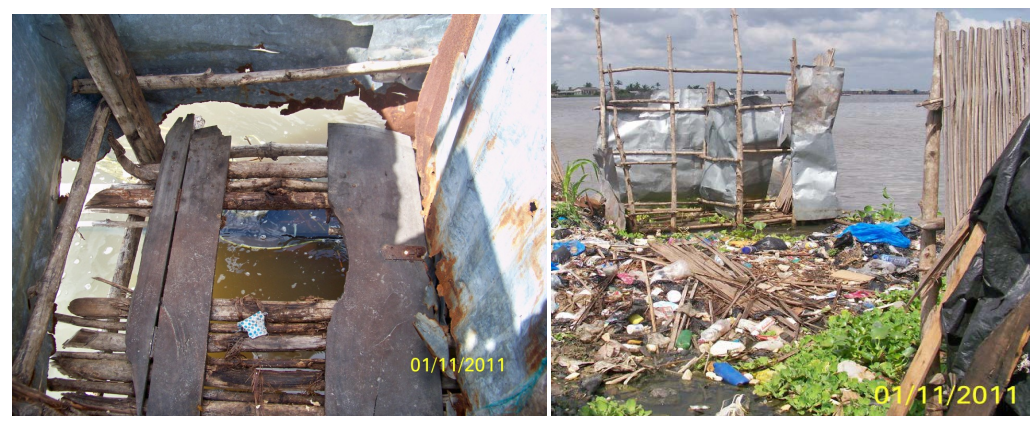

Figure 8. Lagoon latrine.

Table 5. Type of toilet facilities in the houses.

\begin{tabular}{cccccccc}
\hline $\begin{array}{c}\text { Type of black } \\
\text { water facilities }\end{array}$ & WC & Latrine & $\begin{array}{c}\text { WC and } \\
\text { latrine }\end{array}$ & $\begin{array}{c}\text { Manual flush } \\
\text { WC }\end{array}$ & $\begin{array}{c}\text { Sewer } \\
\text { network }\end{array}$ & $\begin{array}{c}\text { Public } \\
\text { toilet }\end{array}$ & $\begin{array}{c}\text { Open } \\
\text { Defecation }\end{array}$ \\
\hline$\%$ & $17.9 \%$ & $55.6 \%$ & $8.3 \%$ & $0.9 \%$ & $2.2 \%$ & $9.0 \%$ & $6.1 \%$ \\
\hline
\end{tabular}

Table 6. Relation between type of toilet facility, house size and income level.

\begin{tabular}{ccccccc}
\hline \multirow{2}{*}{ Toilet facilities } & \multicolumn{3}{c}{ Income level } & \multicolumn{3}{c}{ Household size } \\
\cline { 2 - 7 } & Very Low or low & Medium & High & Small & Medium & Large or very large \\
\hline WC & $3.9 \%$ & $59.3 \%$ & $100.0 \%$ & $58.9 \%$ & $35.3 \%$ & $19.0 \%$ \\
Sewer & $1.6 \%$ & $6.2 \%$ & $0.0 \%$ & $0.0 \%$ & $0.0 \%$ & $0.0 \%$ \\
Latrine & $69.3 \%$ & $25.9 \%$ & $0.0 \%$ & $39.3 \%$ & $61.2 \%$ & $77.6 \%$ \\
Manual Flush WC & $0.8 \%$ & $3.7 \%$ & $0.0 \%$ & $1.8 \%$ & $2.4 \%$ & $0.0 \%$ \\
Public toilet or None & $24.5 \%$ & $4.9 \%$ & $0.0 \%$ & $0.0 \%$ & $1.2 \%$ & $3.4 \%$ \\
\hline
\end{tabular}

Table 7. Relation between type of toilet facility and access to water supply.

\begin{tabular}{cccccc}
\hline \multirow{2}{*}{$\begin{array}{c}\text { In house connections to Public } \\
\text { water supply }\end{array}$} & WC & Sewer & Latrine & Manual Flush WC & Public latrine or None \\
\cline { 2 - 5 } & $50.0 \%$ & $4.1 \%$ & $44.0 \%$ & $0.0 \%$ & $1.8 \%$ \\
Yes & $0.0 \%$ & $0.5 \%$ & $65.2 \%$ & $2.0 \%$ & $32.3 \%$ \\
\hline
\end{tabular}

centage of manual desluging of pit latrines was estimated at 70\% against 30\% for mechanical desludging. It has been reported that mechanical desludging were used by $56 \%$ and $77 \%$ of households respectively in the "Commune IV of Bamako" in Mali and the "Commune of Sam Notaire” in Senegal. The factors that influenced 
the choice of the desludging in these cases are the availability of vacuum tankers and the accessibility of the latrines. But in some areas like Kibera in Nairobi city, the two means are competitive, where the manual desulging is used by $28 \%$ against $33 \%$ for mechanical [6] [14].

The sludges removed by the mechanical vacuum tanks were conveyed to the treatment plant, while that removed by manual means is buried.

Different types of anal cleansing materials were used by respondents (Table 8). Some of the respondents used more than one type of anal cleansing materials; this is the reason why the total is more than $100 \%$.

This study revealed that all the households using manual desludging were using anal cleansing materials other than water and papers. Manual desludging was used because, in addition to its low cost, it allowed a complete desludging, which is impossible with vacuum tanks when there is clogging with anal cleansing material.

About $73.3 \%$ of houses desludged their toilet facilities at least once a year, while only $2.6 \%$ had a desludging interval of greater than once every four years (Table 3). In Ouagadougou, the desludging frequency has been estimated at one year or less for $55 \%$ of latrines and more than 4 years for $10 \%$ of latrines. Even though these frequencies far are higher than the prevision of the latrines' promoters (36 to 48 months), they were still lower than that observed in Cotonou. The high frequency observed in Ouagadougou was associated to the fact that more than $50 \%$ of the surveyed housed disposed of their grey water in their latrines, which is not the case in Cotonou. The high desludging frequency observed in Cotonou was due to the shallow depth of the facilities and the infiltration of groundwater into them. Mean desudging frequencies of 18 months, 10 months, 18 months, 24 months and 8 months have been reported respectively for "Commune VI of Bamako", Kibera city of Kenya, Sam Notaire, Kolack and Saint-Louis in Senegal [6] [14]. The large variability of desludging frequencies are due to the non-standardization of types and size of latrine, the quality of construction, the details of usage, the number of users and also the desludging means.

- Perception of the City Wastewater Management

Respondents had varying opinions on the management of wastewater in Cotonou. They were aware of problems in wastewater management at city level. This can be justified, according to the respondents, by the fact that there are no sanctions or disciplinary measures for those throwing wastewater on the street, and no follow- up regarding the operation of the treatment plant. The majority of respondents (96\%) indicated that management of wastewater in the city is not good and can be improved.

Several solutions were proposed for improvement. Most residents of houses near the lagoon, which discharged all their wastewater directly into the lagoon, indicated that they did not have any sanitation problem; however they proposed the construction of sewers for those who are far from the lagoon. Those disposing of wastewater in the open environment (67\%) acknowledged that this is not a good practice, but they did not have any alternative disposal method. They were ready to discharge into a sewer if it is constructed, but most of them (86\%) were not ready to pay any extra cost. $32 \%$ of the surveyed houses thought that public awareness of wastewater management and/or its effect on public health has to be increased in order to promote changes in behaviour; $10 \%$ thought that it would be necessary to punish the polluters in order to force them to change.

Some $3 \%$ of the surveyed persons think that wastewater management is not their responsibility, but that of the authorities in charge of wastewater treatment.

\section{Wastewater Management at City Level}

- Collection

In Cotonou, wastewater collection, transport and discharge services are provided by private companies and public enterprises (The City Council, the Military Engineering Department). Companies require a permit from the authorities at the wastewater treatment plant management headquarters (SIBEAU) to operate, although no licence is required from the City Council. From 2008 to March 2010, 61 companies (public and private) were registered at SIBEAU.

Table 8. Relation between type of anal cleansing and means of desludging.

\begin{tabular}{ccccc}
\hline & \multicolumn{4}{c}{ Type of anal cleansing material } \\
\cline { 2 - 5 } Means of desludging & Tissue paper & Newspapers or other papers & Water & Others \\
\cline { 2 - 5 } & $61 \%$ & $90 \%$ & $32 \%$ & $10 \%$ \\
\hline Mechanical desludging & $100 \%$ & $100 \%$ & $0 \%$ & $97 \%$ \\
Manual desludging & $0 \%$ & $0 \%$ & $0 \%$ & $3 \%$ \\
\hline
\end{tabular}


Since July 1995, private wastewater collection companies have formed an association called Union desStructures de Vidange, which is funded by the payment of a tax of 150 FCFA (US\$ 0.34) per trip to the wastewater plant management SIBEAU. The objectives of this association are to facilitate dialogue with city authorities and to reduce competition by standardizing the desludging fees.

In this type of wastewater collection management, the companies negotiate their desludging fees directly with clients (houses). The fees vary, depending on the geographical situation in the town, between US\$ 55 to US\$ 75 for a truck of $6 \mathrm{~m}^{3}$ and from US\$ 120 to US\$ 150 for a truck of $12 \mathrm{~m}^{3}$; i.e. an average of US\$ 11 received by the companies per cubic metre of wastewater collected.

On the other hand, each truck entering the treatment plant has to pay an average of US\$2.62 per cubic metre of wastewater plus US\$1.67 per trip to SIBEAU, and an amount of US\$2.25 per trip to the city authorities, as well as the annual truck insurance, which is about US\$ 566, and the auto tax which has increased from US\$ 318 per year in 1998 to US\$ 637 per year at the time of writing. There is also a limit on operation times for trucks due to city traffic management regulations, and of course fuel and spare parts must be purchased. From the statistical data collected from SIBEAU and the information from trucks' owners, each truck discharges an average of $2471 \mathrm{~m}^{3}$ of wastewater per year, which results in an average turnover of US\$26,550 per year for a truck of $12 \mathrm{~m}^{3}$. The global expenditure to run this truck over a year (fuel, fees, insurance, taxes, truck's maintenance, driver's salary) is estimated at US\$22,000. The gross earning is then around US\$ 379 per month, from which other operating costs (communication, stationery, and other staff such as secretary) has to be paid. This is certainly the reason why the desludging companies' owners found that the business is profitable.

- Treatment Plant

All the wastewater collected by the trucks should be conveyed to the treatment plant. Trucks are not authorized to discharge anywhere else.

As mentioned previously, the only waste stabilisation treatment plant in Cotonou is located at Ekpè and is managed by SIBEAU. The City does not have any direct involvement in the plant management, and according to managers, SIBEAU does not receive any assistance from the state or the city apart from the license it received in 1990 when first constructing the plant. Recently, the Benin Environment Agency (ABE) has employed consultants (Eco Plan) to assess the treatment plant.

This type of management is similar to that observed at Sema Saniya, at Bamako-Mali, where wastewater collection, treatment and disposal relied on private companies and NGOs even though the municipality plays a regulatory role. It is quite different from the management in most West African Cities (Ouagadougou in Burkina Faso, Accra and Kumasi in Ghana, Dakar in Senegal), where the municipality has the main role [6].

The problem with type of management is of course that the private companies involved have to make profit to continue operating, and are less concerned with environmental and public health protection.

The SIBEAU plant was designed to treat $180 \mathrm{~m}^{3}$ of wastewater a day. From the data for the period from September 2008 to March 2010, the plant was receiving up to 80 trucks a day. The daily wastewater quantities received ranged from $102 \mathrm{~m}^{3}$ to $816 \mathrm{~m}^{3}$, with a daily average of $477 \mathrm{~m}^{3}$, i.e. 2.65 times the design capacity. The annual quantity registered in 2009 was $144,090 \mathrm{~m}^{3}$, which was about $0.543 \mathrm{~m}^{3} /$ person/year collected, as opposed to the $0.25 \mathrm{~m}^{3} /$ person/year estimated by SIBEAU in 2001 . On average, $70 \%$ of the daily quantity received was from latrines.

Treatment and Disposal

Trucks entering the plant discharge their content through a bar screen into the grit chamber (Figure 9(a)). From this point the wastewater flows to the anaerobic pond (Figure 9(b)).

The effluent from this pond is normally diverted into two series of three aerobic ponds working in parallel, though since 2009 one series has been shut down for the removal of the baffles, which made desludging difficult. Thus, during period of our survey work at the site (September 2009 to April 2010) only one series of ponds was receiving all the incoming wastewater. The liquid effluent from the third pond is directed to the sea. The ponds were full of sludge (Figure 9(b) and Figure 9(c)). The depth measured in each pond from the top of the sludge to the inlet or outlet was less than $10 \mathrm{~cm}$. This vastly reduced the retention time down to less than one hour, with a serious effect on the effluent quality.

The average influent and effluent quality measured by sampling on a weekly basis over three weeks (28/ 09/2010, 23/11/210, 30/12/2010, 16 and 17/01/2012) is shown in Table 9. The average influent $\mathrm{BOD}_{5}$ is far higher than the design $\mathrm{BOD}_{5}$ value of which is $200 \mathrm{mg} / \mathrm{l}$ for $89 \%$ removal. 


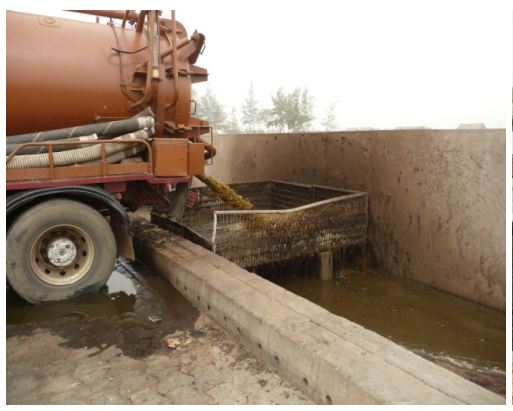

(a)

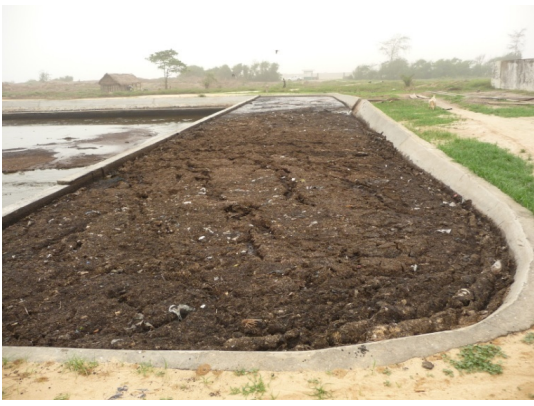

(b)

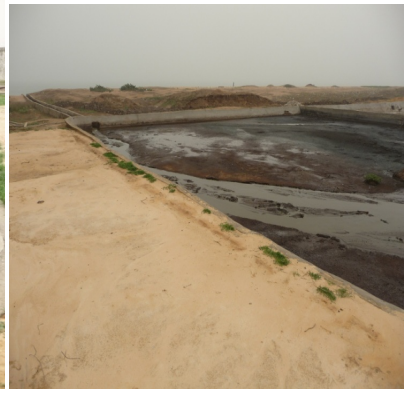

(c)

Figure 9. The treatment plant. (a) The grit chamber; (b) The anaerobic pond; (c) From the third WSP to the sea.

Table 9. Influent and effluent water quality at EKPE’s treatment plant.

\begin{tabular}{cccccc}
\hline Parameter & Unit & Precision & Influent & Effluent & Percentage of removal \\
\hline BOD5 & $\mathrm{mg} / \mathrm{L}$ & \pm 1 & 2375 & 2250 & $5.3 \%$ \\
COD & $\mathrm{mg} / \mathrm{L}$ & $\ldots \ldots \ldots \pm 30$ & 23,350 & 23,000 & $1.5 \%$ \\
TSS & & & & - \\
Temperature & ${ }^{\circ} \mathrm{C}$ & \pm 0.1 & 31 & 33 & - \\
pH & {$[\mathrm{H} 3 \mathrm{O}+]$} & \pm 0.01 & 7.5 & 7.4 & $26.5 \%$ \\
Conductivity & $\mu \mathrm{S} / \mathrm{cm}$ & \pm 0.1 & 17,400 & 12,800 & $21.1 \%$ \\
Dissolved Oxygen & $\mathrm{mg} / \mathrm{L}$ & \pm 0.01 & 0.06 & 0.05 & \\
\hline
\end{tabular}

When the ponds were full of sludge to the extent that wastewater could no longer flow, they were desludged. The sludge was stored on the site and sold as fertilizer to farmers and market gardeners. At present a Chinese market gardening company, based near the plant, is planning to use it to add nutrients to soil. However, the bacteriological quality of the sludge was unknown.

The grit removal from grit chamber was done manually by SIBEAU workers.

According to the management board, seven persons were working on the treatment plant site for operation and maintenance of the whole site (security men, porter, supervisor, and labours).

\section{Conclusion}

A survey has been carried out on wastewater management in Cotonou. It has been shown that there is a predominance of on-site individual sanitation systems, $83 \%$ of houses having either latrines or septic tanks; some houses in areas such as Cité Vie Nouvelle, where there is an old sewer network, are connected to sewers which discharge directly into the sea. $83 \%$ to $97 \%$ of sullage from bathrooms, kitchens and other sources is discharged directly into the environment. Toilet facilities (latrines or septic tanks) are mostly desuldged by mechanical means and transported and disposed of at the only treatment plant which is a waste stabilization pond plant and is running vastly above its design capacity and beyond its $\mathrm{BOD}_{5}$ designed values. The plant also lacks maintenance and the effluent going to the sea is strong (COD up to $23,000 \mathrm{mg} / \mathrm{l}$ ) and does not meet any discharging guidelines. Most residents surveyed (96\%) thought that wastewater management systems can be improved. These results show that the existing management system works with regard to the collection of black water (from toilets) from households and its transportation to the treatment plant; however the treatment is not performing satisfactorily due to overloading and lack of maintenance.

\section{References}

[1] Organization, W.H. (2010) Water, Sanitation and Hygiene Links to Health Facts and Figures-Updated November 2004. WHO, Geneva.

[2] Montgomery, M.A. and M. Elimelech (2007) Water and Sanitation in Developing Countries: Including Health in the Equation. Environmental Science \& Technology, 41, 17-24. http://dx.doi.org/10.1021/es072435t

[3] OMS (2010) Evaluation annuelle mondiale de L'onu-eau sur l'assainissement et l'eau potable. Organisation Mondiale 
de la santé (OMS).

[4] WHO and UNICEF (2012) Progress on Sanitation and Drinking-Water-2012 Update. World Health Organization, Geneva.

[5] UNION, I.P. (2008) The Millennium Development Goals Report 2008.

[6] KOANDA, H. (2006) Vers un assainissement urbain durable en Afrique subsaharienne: Approche innovante de planification de la gestion des boues de vidange in Faculté Environnement Naturel, Architectural et Construit 2006, École Polytechnique Fédérale de Lausanne.

[7] Morella, E., Foster, V. and Banerjee, S.G. (2008) Climbing the Ladder: The State of Sanitation in Sub-Saharan Africa. Background Paper, 13.

[8] Mbéguéré, M., Gning, J., Dodane, P. and Koné, D. (2010) Socio-Economic Profile and Profitability of Faecal Sludge Emptying Companies. Resources, Conservation and Recycling, 54, 1288-1295. http://dx.doi.org/10.1016/j.resconrec.2010.04.008

[9] Cotonou, L.M.D. (2011) La ville de Cotonou, La Mairie de Cotonou. www.mairiedecotonou.com

[10] ASCECNA (2008) Données pluviométriques de Cotonou: Station de l'Aéroport de Cotonou 2008, ASECNA.

[11] INSAE-BENIN (2002) Recensement Général de l’Habitat et la Population 2002, INSAE-BENIN.

[12] Collignon, B. (2002) Les entreprises de vidange mécanique des systèmes d'assainissement autonome dans les grandes villes africaines. Châteauneuf de Gadagne, Hydroconseil.

[13] SEIDL, M., J.M. MOUCHEL, U. EIER, and C. Aquadev (2003) Valorisation des eaux usées par lagunage dans les pays en voie de développement. Centre dÉenseignement et de recherche Eau Ville Environnement, centre conjoint de lÉENGREF, de lÉENPC et de lÉUPVM.

[14] Bolomey, S., D. Koné, and M. Strauss (2003) Amélioration de la gestion des boues de vidange par le renforcement du secteur privé local: Etudes et Outils Cas de la Commune VI du District de Bamako. 2003, Eawag/Sandec, 48 p. http://www.sandec.ch/FaecalSludge/Documents/Renforcement_secteur_prive.pdf 